\title{
A STUDY ON THE INCIDENCE OF GOALS AND THE RELATIONSHIP BETWEEN SCORING THE FIRST GOAL AND WINNING THE MATCH IN THE HUNGARIAN BEACH SOCCER CHAMPIONSHIP
}

\author{
Luiz Escobar Passos da Silva1, László Balogh², József Márton Pucsok²
}

(1) Bahamas Football Association, Bahamas, head coach;

(2) University of Debrecen, Institute of Sport Sciences, Debrecen, Hungary

\begin{abstract}
Although beach soccer has become increasingly popular in recent years an only a minimal number of scientific research has been conducted in this area. The beach soccer is characterized by high intensity (HR max above $90 \%$ ) intermittent movements, which primarily requires the involvement of the anaerobic metabolic system. The objective of this study was: (i) to analyze the incidence of goals in the Hungarian Beach Soccer Championship in relation to the periods of the game that tend to occur; (ii) to identify the team that scored the first goal of the game, analyzing the influence of this event on the final result (iii) to identify and quantify the periods of the match won by the winner team. We examined all the goals ( $n=1.065)$ in the Hungarian Championship (2016-2017) of beach soccer. We found that nearly 38 percent of goals are scored in the last period of the matches, the team that scores the first goal of the game features an average 74.44 percent probability of winning. We observed, that almost 24 percent of the teams, which achieved overall success also earned the 1st and 3rd periods. Thus, it is suggested that the higher incidence of goals in the 3rd period of the matches is associated mainly with the interaction of physical and psychological factors. Regarding the influence of the first goal on the final result, we assumed that the psychological factor appears to interfere with greater relevance.
\end{abstract}

Keywords: beach soccer, incidence of goals, final result 


\section{INTRODUCTION}

The sport of beach soccer is a relatively young sport, originally developed and launched in Brazil in 1995. Since 2005, it has passed the directions and regulations of the FIFA (Fédération Internationale de Football Association) and gained greater visibility and credibility worldwide (Escobar et al., 2010; Shimakawa et al., 2016). Two teams play its innovative format, the beach soccer, each consisting of five players including a goalkeeper. The playing time is divided into three periods of 12 minutes with 3-minute intervals between the periods. Further, it is characterized by unique technical elements such as fouls (no walls), throw in - which may be executed with feet or hands. Unlike soccer, the beach version allows unlimited substitution of players, but and no draws, the dimensions of the playing area also differs. The pitch is rectangular $(37 \mathrm{x} 28 \mathrm{~m})$. "The touchline must be longer than the goal line. The distance (inside measurement) between the posts is $5.5 \mathrm{~m}$, and the distance from the lower edge of the crossbar to the ground is $2.2 \mathrm{~m}$ " (FIFA, 2015). These areas are purposely designed to provide a greater frequency of offensive actions, with a higher probability of scoring goals in a more dynamic-fashion (Pereira et al., 2007; as cited in Escobar et al., 2012).

Beach soccer, like any other game or sports, has six attributes as earlier described by Bayer (1994) and later Morato (2004) such as a ball or similar implement, a space of the game, opponents, partners, a target to attack and another to defend and specific rules. Coaches professionals in sport may easily identify certain similarities with other ball sports like traditional soccer, futsal, basketball, and handball among others. These similarities were named by Bayer (1994) as "operational principles," which are further divided into three principles of attack and three principles of defense. The attack ones are possession of the ball, progression towards the opponent's target and the finishing of action, resulting in a point or goal. The principles of defense are: recovering the ball, preventing the progression of the opposing team and protecting the target itself (Morato, 2004). However, in beach soccer it is possible to make unlimited substitutions of the players, this constant rotation of the athletes enables to maintain a high level of intensity throughout the match (Álvarez-Medina et al. , 2002; Castellano \& Casamichana, 2010; Dias \& Santana, 2006; Escobar et al., 2012). In this sense, beach soccer is characterized by intermittent high-intensity movements (intensities usually above $90 \%$ ), with high anaerobic system demand (Barbosa, 1998; Pereira et al., 2007; Castellano \& Casamichana, 2010; as cited in Escobar et al., 2011).

The MLSZ (Hungarian Football Federation) has recently established a department of beach soccer, with the primary purpose of professional, organizational and infrastructural development, to increase the recognition of sport at home and abroad. With the growing number of teams, the federation launched the national championship of beach soccer in Hungary. The competition season includes the summer months of July and August, with ten teams, each club plays twice against the others (the double round robin system) and the best four placed after the regular season phase goes to the finals. Scoring a goal is the primary objective of this sport, this moment of the game reflects the continued imbalance of one or several components, which influences the progress of team preparation (Leitão et al., 2003). Success during the game largely depends on the level of development of perceptual and intellectual abilities of athletes, especially in association with other physical, tactical and psychological.factors that determine performance. 
Nowadays, electronic resources provide valuable support for coaches, trainers, doctors, physiotherapists, psychologists, and nutritionists to improve the competitive performance of their teams. It is necessary for any team to improve the physical, technical, tactical, psychological performance of their athletes, also to keep in mind the nutritional factors in order to achieve their goals.

\section{PURPOSE}

The present study aims to: (i) analyze the incidence of goals in the Hungarian Beach Soccer Championship in relation to the periods of the game that tend to occur; (ii) identify the team that scored the first goal of the game, analyzing the influence of this event on the final result (iii) Identify and quantify the periods of the match won by the winner team.

\section{MATERIALS AND METHODS}

This study is characterized as observational, descriptive and analytical. Data on the number of goals and the moment they were scored in the matches of the Hungarian Beach Soccer Championship were obtained from MLSZ (www.mlsz.hu) site, involving data of the official summaries of the games. For further analysis, we divided the beach soccer game into four periods (1st-12th min.; 13th-24th min.; 25th-36th min. and extra time 37 th-40th $\min$.$) .$

We analyzed data of 90 games in total (only the regular season) with 1065 goals during the Hungarian Beach Soccer Championship (2016-2017). We investigated the relationship between scoring the first goal of the game and the final result obtained by the same team. Therefore, we analyzed goals scored only during the regular time of the game (36 $\mathrm{min})$.

\section{RESULTS}

In the Hungarian championship (2016-2017) of beach soccer, 90 games were examined, where 1065 goals were scored, which represents an average of 11.8 goals per game. The recorded number of goals occurred with the following distribution: 322 goals $(30.23 \%)$ in the 1 st period, 332 goals $(31.17 \%)$ in the 2 nd period, 403 goals $(37.84 \%)$ in the 3rd period and eight goals (0.75\%) in extra time (Table 1$)$. 
Vol 4, No 2 (2021): Stadium -Hungarian Journal of Sport Sciences

https://doi.org/10.36439/shjs/2021/2/10559

Table 1: Distribution of goals scored in Hungarian Beach Soccer Championship 2016 - 2017, according to the periods of the game

\begin{tabular}{|c|c|c|c|c|c|c|c|}
\hline $\begin{array}{c}\text { Goals } \\
\text { period }\end{array}$ & $\begin{array}{c}\text { 2nd } \\
\text { period }\end{array}$ & $\begin{array}{c}\text { 3rd } \\
\text { period }\end{array}$ & $\begin{array}{c}\text { Extra } \\
\text { time }\end{array}$ & Total & Matches & Average \\
\hline Round 1 & 80 & 72 & 98 & 4 & 254 & 22 & 11.5 \\
\hline Round 2 & 75 & 74 & 97 & 0 & 246 & 23 & 10.7 \\
\hline Round 3 & 85 & 95 & 97 & 4 & 281 & 22 & 12.8 \\
\hline Round 4 & 82 & 91 & 111 & 0 & 284 & 23 & 12.3 \\
\hline Total & 322 & 332 & 403 & 8 & 1065 & 90 & 11.8 \\
\hline$\%$ & 30.23 & 31.17 & 37.84 & 0.75 & 100.0 & & \\
\hline Average & 81 & 82.5 & 97.5 & 2 & 267.5 & 22.5 & 11.9 \\
\hline $\begin{array}{l}\text { Standard } \\
\text { Deviation }\end{array}$ & 4.20 & 11.69 & 6.85 & 2.31 & 19.09 & 0.58 & 0.92 \\
\hline
\end{tabular}

Table 2. demonstrates the relationship between the team that won the game and the distribution of periods of the game won by the same team. The results of our data analysis suggest, that $4,4 \%$ of the teams won the 1 st period, $11.1 \%$ the 2 nd period, $5.6 \%$ the third period only, $15.6 \%$ on the 1 st and 2 nd periods, $23.3 \%$ on the 1 st and 3 rd periods, $11.1 \%$ on the 2 nd and 3rd periods and $28.9 \%$ won all periods of the match.

Table 2: Comparison between the winner of periods and the winner of the matches

\begin{tabular}{|c|c|c|c|c|c|c|c|c|}
\hline $\begin{array}{c}\text { Matches } \\
\text { won by the } \\
\text { team }\end{array}$ & $\begin{array}{c}\text { 1st } \\
\text { period }\end{array}$ & $\begin{array}{c}\text { 2nd } \\
\text { period }\end{array}$ & $\begin{array}{c}\text { 3rd } \\
\text { period }\end{array}$ & $\begin{array}{c}\text { 1st and } \\
\text { 2nd } \\
\text { period }\end{array}$ & $\begin{array}{c}\text { 1st and } \\
\text { 3rd } \\
\text { period }\end{array}$ & $\begin{array}{c}\text { 2nd and } \\
\text { 3rd } \\
\text { period }\end{array}$ & $\begin{array}{c}\text { 1st, 2nd } \\
\text { and 3rd } \\
\text { period }\end{array}$ & $\begin{array}{c}\text { Total } \\
\text { Matches }\end{array}$ \\
\hline Round 1 & 2 & 2 & 3 & 3 & 6 & 4 & 2 & 22 \\
\hline Round 2 & 0 & 4 & 1 & 2 & 5 & 3 & 8 & 23 \\
\hline Round 3 & 2 & 1 & 0 & 5 & 4 & 1 & 9 & 22 \\
\hline Round 4 & 0 & 3 & 1 & 4 & 6 & 2 & 7 & 23 \\
\hline Total & 4 & 10 & 5 & 14 & 21 & 10 & 26 & 90 \\
\hline$\%$ & 4.4 & 11.1 & 5.6 & 15.6 & 23.3 & 11.1 & 28.9 & \\
\hline Average & 1 & 2.5 & 1.25 & 3.5 & 5.25 & 2.5 & 6.5 & 22.5 \\
\hline $\begin{array}{c}\text { Standard } \\
\text { Deviation }\end{array}$ & 1.15 & 1.29 & 1.26 & 1.29 & 0.96 & 1.29 & 3.11 & 0.58 \\
\hline
\end{tabular}

Analyzing the games of the Hungarian Beach Soccer Championship (2016-2017), we concluded, that the team scored the first goal of the game reached the final victory as well majority (74.44\%) of the matches played. 
Vol 4, No 2 (2021): Stadium -Hungarian Journal of Sport Sciences

https://doi.org/10.36439/shjs/2021/2/10559

Table 3: Comparison between the first goal scored and the winner ones in Beach Soccer Hungarian Championship 2016-2017

\begin{tabular}{|c|c|c|c|c|c|c|c|}
\hline $\begin{array}{c}\text { Hungarian Championship } \\
\mathbf{2 0 1 6 - 2 0 1 7}\end{array}$ & $\begin{array}{c}\text { Round } \\
\mathbf{1}\end{array}$ & $\begin{array}{c}\text { Round } \\
\mathbf{2}\end{array}$ & $\begin{array}{c}\text { Round } \\
\mathbf{3}\end{array}$ & $\begin{array}{c}\text { Round } \\
\mathbf{4}\end{array}$ & Average & Total & $\begin{array}{c}\text { Standard } \\
\text { Deviation }\end{array}$ \\
\hline $\begin{array}{c}\text { Matches won by the team } \\
\text { scoring first (\%) }\end{array}$ & 63.6 & 60.9 & 95.5 & 78.3 & 74.44 & & \\
\hline Total matches per round & 22 & 23 & 22 & 23 & 22.5 & 90 & 0.58 \\
\hline $\begin{array}{c}\text { Total matches won by the } \\
\text { team scoring first }\end{array}$ & 14 & 14 & 21 & 18 & 16.75 & 67 & 3.40 \\
\hline
\end{tabular}

\section{DISCUSSION}

The main purpose of this study was to examine the incidence of goals in the games of the Hungarian Beach Soccer Championship about the periods of the game that tend to occur. The secondary purpose was to identify the team, that scored the first goal of the game, and investigate the influence of this event on the final result, as well as identify and quantify the periods of the match won by the winning team.

\section{EXAMINATION OF SCORED GOALS}

The data in Table 1. indicate that the highest incidence of goals occurred in the last period of matches of the Hungarian Beach Soccer Championship (37.84\%). Our data supported earlier findings by Leite (2016), who observed a higher incidence of goals in the 3rd period (36.4\%), compared to the matches played during the regular FIFA Beach Soccer World Cup season.

It is important to mention the disadvantage imposed by the playing surface in beach soccer (Castellano \& Casamichana, 2010). Lejeune et al. (1998) suggested that running on sand requires 1.6 times more energy expenditure compared to running on the firm ground, supposedly generating greater performance of mechanical work on muscles and tendons. Bishop (2003) mentions that sandy soil absorbs some of the energy applied, thus reducing the reaction force. This surface may lead to a lower maximum speed of movement due to sand instability (Giatsis et al., 2004, cited in Leite, 2016). Results as shown in table 1 , demonstrate the decrease in physical performance, and acceleration dynamics, mainly due to the sandy surface, which may lead to fatigue. Another important aspect of the performance is psychological because the rule of the game does not allow a draw, it puts greater pressure to the players. According to Dias and Santana, (2006) the last period of the game is critical in a sense, that during this final moment players tend to make mistakes more frequent. In addition to the tactical issues, the team that is at a disadvantage in the last minutes of the game manages to continuously launch offensive actions, trying to create situations to score goals. We hypothesized that the implementation of technical-tactical activities at the final phase of the game is significantly influenced by the elevated physical and mental pressure on the players. Our results supported (Table 1), the assumptions mentioned above, the higher intensity experienced during this period may facilitate the scoring of goals. 

THE MATCH

After analyzing data represented at (Table 2), we found that $4.4 \%$ of the teams only won the 1 st period, $11.1 \%$ only the 2 nd period, $5.6 \%$ only the third period, $15.6 \%$ on the 1 st and 2 nd period, $23.3 \%$ on the 1 st and 3rd period, $11.1 \%$ on the 2 nd and $3 r d$ period and $28.9 \%$ won all periods of the match.

We suggested that $28.9 \%$ of the teams won all the periods and $23.3 \%$ on the 1 st and 3rd period. Several researchers (Escobar et al., 2011; Escobar \& Lacerda, 2010) indicated that much of the activity of beach soccer players' movements are based on anaerobic metabolism. Therefore, the dynamic characteristics of the game the high mental and physical demand are evident throughout the entire game. It seems that the first period and the third period are crucial in obtaining the final result of the game. It is critical to investigate each element of the game to reach better performance in the physical, cognitive, tactical, technical components of the game.

\section{RELATIONSHIP BETWEEN SCORING THE FIRST GOAL AND THE FINAL RESULT OF THE MATCH}

Before analyzing any data, it is vital to realize the structure of the competition. In the Hungarian championship, athletes may play several games on consecutive days, even up to two matches per day. In the Hungarian championship, the games always take place on weekends. Playing five to six games per weekend is very demanding mentally and physically too. According to the data presented at Table 3, the team that scores the first goal in matches of the Hungarian beach soccer championship has a high probability of winning (average of 74.44\%). If an equal number of goals achieved at the end of the official match-time, an extra-time or penalty kicks may follow to decide the final result. The ratio (mean 74.44\%) between the first goal and the successful result at the end of each match is shown in Table 3. Other researchers also found relatively high probability, Leite (2016) calculated an average of $62 \%$ ratio between the first goal and the overall victory during the FIFA Beach Soccer World Cup Series.

\section{CONCLUSIONS}

The complexity of beach soccer based on the continuous interactions of the tactical, technical, physical and psychological components of the game. Because of the multifactorial nature of this sport, it is very challenging for both athletes and coaches to adapt to each game situations progressively. The mental aspect seems to be one of the main factor associated with the influence of the first goal on the final result of the game. However, other factors, such as injuries, fatigue caused by the increased physical and mental demand - due to games on consecutive days - may also influence the performance of teams. Thus, the importance of being the team to score the first goal creates an obvious psychological advantage through boosting self-confidence for the team members (Leite \& Barreira, 2014).

According to the data presented in this study, we may conclude that there was a higher incidence of goals in the 3rd period of games, throughout the Hungarian championship of beach soccer, associated mainly with the combination of physical and psychological 
factors. Beach soccer is an intermittent sport of high intensity, with more than half the time is spent in exercise intensities greater than $90 \%$ of HRmax, resulting in a high-level involvement of the anaerobic energy system. For the winning team's perspective, the study presented interesting data, indicating that winning the 1st and 3rd periods are crucial for overall success. We suggest that the results of our study may serve as a methodological reference for sports professionals to organize and conduct more effective training programmes.

\section{REFERENCES}

Álvarez-Medina, J., Giménez-S., L., Corona-V.P., \& Manonelles-M., P. (2002). Necesidades cardiovasculares y metabólicas del fútbol sala: análisis de la competición. Apunts: Educación física y Deportes, 67, 45-51.

Alves, J. F. (2003). Surgimento e trajetória do beach soccer no Espírito Santo. 2003. 36 f. Monografia (Licenciatura Plena em Educação Física) - Curso de Educação Física, Esporte e Lazer, Centro Universitário Vila Velha, Vila Velha.

AMERICAN COLLEGE OF SPORTS MEDICINE (2007). Diretrizes do ACSM para os testes de esforço e sua prescrição. 7. ed. Rio de Janeiro: Guanabara Koogan.

Barbosa, Marco Octavio Simões (1998). Beach Soccer: da iniciação a competição. Rio de Janeiro: Sprint.

Bayer, C. O. (1994). Ensino dos desportos coletivos. Lisboa: Dinalivro.

Bishop, D. A (2003). Comparison between land and sand-based tests for beach volleyball assessment. Journal of Sports Medicine and Physical Fitness 43(4): 418-423.

Bompa, T. (2002). Periodização: teoria e metodologia do treinamento. São Paulo: Editora Phorte.

Bompa, T. (2005). Treinando atletas de desporto coletivo. São Paulo: Phorte.

Castellano, J. \& Casamichana, D. (2010). Heart rate and motion analysis by GPS in beach soccer. Journal of Sports Science and Medicine, v. 9, p 98-103.

Dias, R., \& Santana, W. (2006). Tempo de incidência dos gols em equipes de diferentes níveis competitivos na copa do mundo de futsal. Revista EFDeportes.com, 11, 101.

Escobar, L. \& Lacerda, A. (2010). Identificação e caracterização dos estados de humor de atletas da seleção carioca de beach soccer durante o campeonato brasileiro. Revista movimento \& percepção, Espírito Santo do Pinhal, São Paulo, v. 11, n.16, p. 107-119. 
Escobar, L., Martins, F., Oliveira, B., \& Henrique, J. (2011). Comparação entre testes aeróbios realizados em solos distintos em atletas de futebol de areia. Revista EFDeportes.com, n. 158.

Escobar, L., Martins, F., \& Manso, W. (2012). Antropometria, composição corporal e indicadores de potência anaeróbia obtidos com o Rast Test de atletas da seleção brasileira de beach soccer. Revista EFDeportes.com, n. 169.

Fazolo, E. et al. (2005). A Dermatoglifia e a somatotipologia no alto rendimento do beach soccer - seleção brasileira. Rev Educação Física, v. 130, p. 45-51.

FIFA, Beach Soccer Laws of the Game 2015. 2015 https://footballtechnology.fifa.com/media/1021/footballs_beach_soccer_laws_of_the_game.pdf.

Accessed January 31, 2018

Giatsis, G. et al. Biomechanical differences in elite beach-volleyball players in vertical squat jump on rigid and sand surface. Sports Biomech, v.3, n.1, p.145-58, 2004.

Leitão, R. A., Guerreiro Junior, F. C., Zago, L., \& Moraes, A. C. Análise da incidência de gols por tempo de jogo no campeonato brasileiro de futebol 2001: estudo comparativo entre as primeiras e últimas equipes colocadas da tabela de classificação (2003) Disponível em: http://www.unicamp.br/fef/publicacoes/conexoes/v1n2/6_analise.pdf - Acesso em 17 de jul. 2017.

Leite, W. (2016). Physiological Demands In Football, Futsal And Beach Soccer: A Brief Review European Journal of Physical Education and Sport Science - Vol. 2.

Leite, W., \& Barreira, D. (2014). Are the team sports soccer, futsal and beach soccer similar? International Journal of Sports Science, 4 (6A), 75-84.

Lejeune, T.M., Willems, P.A. \& Heglund, N. C. (1998). Mechanics and energetics of human locomotion on sand. J Experimental Biol, v. 201, p. 2721-80.

Morato, M. P. (2004). Treinamento defensivo no futsal. Lecturas Educación Física y Deportes, Buenos Aires, v. 77, n. Ano 10, p. 1-13.

Pereira, R.V., Azevedo, R.N., \& Soares, A.J. (2007). Beach soccer: métodos e técnicas da iniciação ao alto rendimento. Rio de Janeiro: Colina.

Pedroza Jr., E.T. (2014). Perfil caracterizador e análise de gols da seleção brasileira de beach soccer na Intercontinental Cup Dubai 2012. Revista Brasileira de Futsal e Futebol. São Paulo. Vol. 6. Núm.19. p. 51-57.

Scarfone, R. et al. (2009). Match demands of beach soccer: a case study. In: Book of abstracts of 14th Annual Congress of the European College of Sport Science, Oslo-Norway, n 54, p. 24-29. 
Shimakawa et al. (2016). Beach Soccer Injuries During the Japanese National Championships. The Orthopaedic Journal of Sports Medicine, 4(1).

Silva, C. D. (2006). Fadiga: evidências nas ocorrências de gols no futebol internacional de elite. Lecturas Educación Física y Deportes, Revista Digital, Buenos Aires, Año 11, nº 97.

Silva, C. D. \& Junior, R. M. (2006). Análise dos gols ocorridos na 18ª Copa do Mundo de futebol da Alemanha 2006. Lecturas Educación Física y Deportes, Revista Digital, Buenos Aires, Año 11, nº 101.

Thomas, C. et al. (2005). Monocarboxylate transporters, blood lactate removal after supramaximal exercise, and fatigue indexes in humans. Journal of Applied Physiology, Bethesda, v. 98, p. 804-809.

Thomas, C. et al. (2004). Relationship between maximal muscle oxidative capacity and blood lactate removal after supramaximal exercise and fatigue indexes in humans. Journal of Applied Physiology, Bethesda, v. 97, p. 2132-2138.

Zamparo, P., Perini, R., Orizio, C., Sacher, M. \& Ferretti, G. (1992).The energy cost of walking or running on sand. European Journal of Applied Physiology 65, 183-187. 